\title{
HPV Types in Turkey: Multicenter Hospital Based Evaluation of 6388 Patients in Turkish Gynecologic Oncology Group Centers
}

\author{
Türkiye'deki HPV Tipleri:Türk Jinekolojik Onkoloji Grubuna Üye \\ Merkezlere Başvuran 6388 Hastanın Retrospektif Analizi
}

\begin{abstract}
Polat DURSUN', Ali AYHAN', Levent MUTLU' ', Mete ÇAĞLAR', Ali HABERAL', Taygun GÜNGÖR², Mustafa ÖZAT², Emre ÖZGÜㄹ, Anıl ONAN ${ }^{3}$, Çağatay TAŞKIRAN ${ }^{3}$, Haldun GÜNER ${ }^{3}$, Hakan YETiMALAR ${ }^{4}$, Burcu KASAP ${ }^{4}$, Kunter YÜCE ${ }^{5}$, M. Coşkun SALMAN ${ }^{5}$, Berkan SAYAL ${ }^{5}$, Selen DOĞAN ${ }^{5}$, Müge HARMA ${ }^{6}$, Mehmet HARMA ${ }^{6}$, Mustafa BASARAN ${ }^{6}$, Hüseyin AYDOĞMUŞ ${ }^{7}, Y_{\text {Yusuf ERGÜN }}{ }^{7}$, Salim ŞEHIRALi $^{8}$, Emre GÜLTEKIN ${ }^{8}$, Şükran KÖSE ${ }^{8}$, Yusuf YILDIRIM ${ }^{8}$, Müfit YENEN ${ }^{9}$, Murat DEDE ${ }^{9}$, İbrahim ALANBAY ${ }^{9}$, Rıza KARACA ${ }^{9}$, Jale METiNDiR ${ }^{10}$, Levent KESKIN ${ }^{11}$, Işık ÜSTÜNER ${ }^{11}$, Filiz AVŞAR ${ }^{11}$, Hasan YÜKSEL ${ }^{12}$, Selim KIRDAR ${ }^{12}$
\end{abstract}

Department of Obstetrics and Gynecology, 'Başkent University, Faculty of Medicine, ANKARA, TURKEY, '2Zekai Tahir Burak Maternity Hospital, ANKARA, TURKEY, ${ }^{3}$ Gazi University, Faculty of Medicine, ANKARA, TURKEY, ${ }^{4}$ Atatürk Education and Research Hospital, IZMIR, TURKEY,

${ }^{5}$ Hacettepe University, Faculty of Medicine, ANKARA, TURKEY, ${ }^{6}$ Karaelmas University, Faculty of Medicine, ZONGULDAK, TURKEY,

${ }^{7}$ Ankara Education and Research Hospital, ANKARA, TURKEY, ${ }^{8}$ Ege Maternity Hospital, iZMiR, TURKEY, ${ }^{9}$ Gülhane Military Medical Academy, ANKARA, TURKEY,

${ }^{11}$ Atatürk Education and Research Hospital, ANKARA, TURKEY and ${ }^{12}$ Adnan Menderes University, Faculty of Medicine, AYDIN, TURKEY

${ }^{10}$ Department of Gynecologic Oncology, Ankara Oncology Hospital, ANKARA, TURKEY

\section{ABSTRACT}

Objective: To evaluate the prevalence of HPV DNA and cervical cytological abnormalities, to compare cervical cytology results and HPV DNA and to define HPV types distribution in a large series of Turkish women who have undergone HPV analysis in hospitals that are members of the Turkish Gynecological Oncology Group.

Material and Method: Between 2006 and 2010, a total of 6388 patients' data was retrospectively evaluated at 12 healthcare centers in Turkey. Demographic characteristics, cervical cytology results, HPV status and types were compared.

Results: The mean age of the patients was $38.9 \pm 10.2$. Overall, $25 \%$ of the women were found to be HPV positive. Presence of HPV-DNA among patients with abnormal and normal cytology was $52 \%$ and $27 \%$, respectively. There was significant difference with respect to decades of life and HPV positivity $(\mathrm{p}<0.05)$. HPV was positive in (within the HPV (+) patients) $37 \%, 9 \%, 27 \%, 20 \%, 22 \%$, and $41 \%$ of the ASCUS, ASC-H, LSIL HSIL, glandular cell abnormalities, and SCC cases respectively The most common HPV types in our study were as follows; HPV 16 (32\%), HPV 6 (17\%), HPV 11 (9\%), HPV 18 (8\%), HPV 31 (6\%), HPV 51 (5\%), HPV 33 (3\%).

Conclusion: In this hospital based retrospective analysis, HPV genotypes in Turkish women with normal and abnormal cytology are similar to those reported from western countries. Further population based prospective multicenter studies are necessary to determine non-hospital based HPV prevalence in Turkish women.

Key Words: Human papillomavirus DNA tests, Mass screening, Uterine cervical neoplasms, Vaginal smears, Turkey

(Turk Patoloji Derg 2013, 29:210-216)

Received : 28.06.2013 Accepted : 22.08.2013

\section{ÖZ}

Amaç: Türkiyedeki HPV tiplerinin geniş bir seri ile ortaya konması amacı ile Türk Jinekolojik Onkoloji grubuna üye hastanelerde HPV analizi yapılan hastaların sonuçlarının retrospektif olarak değerlendirilmesi ve sitolojik anormalliklerdeki HPV tiplerinin belirlenmesi.

Gereç ve Yöntem: 2006 ve 2010 yılları arasında 12 ayrı merkeze başvuran smear ve HPV analizi yapilan toplam 6388 hasta retrospektif olarak incelenmiştir. Hastaların demografik bilgileri, smear sonuçları, HPV tipleri online olarak toplanıp analiz edilmiştir.

Bulgular: Ortalama hasta yaşı $38.9 \pm 10.2$ idi. Tüm grup değerlendirildiğinde, \%25 hastada HPV pozitif olarak saptandı. Anormal sitolojisi olanlarda HPV pozitifliği \%57 iken normal pap testi olanlarda HPV pozitifliği \%27 oranında tespit edildi. Hastaların yaşam dekadları ile HPV pozitifliği arasında anlamlı bir ilişki bulundu $(\mathrm{p}<0,05) \mathrm{HPV}$ pozitifliği ASCUS, ASC-H, LSIL, HSIL, glandüler anormallikler ve skuamöz hücreli karsinom için sırasıyla \%37, \%9, \%27, \%20, \%22, \%41 idi. En sık görülen HPV tipleri sırasıyla HPV 16 (\%32), HPV 6 (\%17), HPV 11 (\%9), HPV 18 (\%8), HPV 31 (\%6), HPV 51 (\%5), HPV 33 (\%3) idi.

Sonuç: Bu hastane temelli retrospektif analizde HPV tipleri gelişmiş batı ülkelerinde rapor edilen tiplerle benzer olarak tespit edildi. Ülkemizdeki gerçek popülasyon temelli HPV prevalansı ve tiplerinin belirlenmesi için hastane temelli olmayan çok merkezli geniş sayıda hasta içeren serilere ihtiyaç vardır.

Anahtar Sözcükler: Human papillomavirus DNA testleri, Kitle taraması, Uterin servikal tümörler, Vaginal yayma, Türkiye

Correspondence: Polat DURSUN

Başkent Üniversitesi, Tip Fakültesi, Kadın Hastalıkları ve Doğum Anabilim Dall, ANKARA, TURKEY

E-mail: pdursun@yahoo.com Phone: +90 3122324400 


\section{INTRODUCTION}

Worldwide, cervical cancer is the second most common and the fifth deadliest cancer in women $(1,2)$. It affects about 16 per 100,000 women per year and kills about 9 per 100,000 per year (3). Worldwide, in 2008, it was estimated that there were 473,000 cases of cervical cancer, and 253,500 deaths per year majority of which is preventable with the HPV vaccine (4). The vaccine is also effective against type 6 and 11 which cause more than $90 \%$ of anogenital warts and recurrent respiratory papillomatosis. Therefore accurate information about HPV prevalence is needed to make vaccination recommendations. The widespread use of cervical screening programs has dramatically reduced the incidence of invasive cervical cancer (5).

What is less known in Turkey is the prevalence of cervical abnormalities and HPV type distribution. This information is important for a better understanding of which prevention strategies, such as screening programs, public health education and vaccines are likely to be effective. Previous studies have reported that HPV prevalence among lowrisk Turkish women ranges between 2- $20 \%$ (6). However, reliable data on HPV type distribution in this population is lacking. Therefore we performed a multicenter study with the aim of improving knowledge with regard to the prevalence of the HPV DNA and to determine the distribution of HPV types among women with normal and abnormal cytology.

\section{MATERIAL and METHODS}

This is a multicenter retrospective study, which was conducted in twelve tertiary gynecology centers in Turkey. After obtaining the ethical approval of Başkent University Ethics Committee, a total of 12 healthcare centers in Turkey agreed to participate in the study. Between January 2006 and December 2010, a total of 6388 consecutive patients who underwent a pelvic examination by a gynecologist were recruited for this retrospective analysis. Current pregnancy, previous diagnosis, or treatments for cervical, vulva or vaginal cancer, previous hysterectomy or cervical conisation, previous history of chemo-radiotherapy for cervical carcinoma were excluded from the analysis. Very few virgins underwent a gynecological examination. Therefore, the following analyses were restricted to those women who reported being sexually active. Data were collected from patient files, pathology/cytology reports, and hospital records. Patients' demographic characteristics, cervical cytology results, HPV status, and types were collected from each participating center. These data were sent to the principal investigators, thus final analysis was performed at Başkent University School of Medicine. All cervical specimens were collected via the same standardized protocol. Samples of exfoliated cervical cells were obtained using a cytobrush. After preparation of a standard cervical smear, the remaining cells were placed in tubes with $0.9 \%$ saline. These tubes were transferred to the microbiology laboratory for HPV-DNA analysis. Papanicolaou or liquid-based cytology smears were stained and read by local cytopathologists and classified according to the Bethesda system (7). HPV DNA detection and genotyping performed by Hybrid Capture-II (used only at Hacettepe University) and PCR as described previously and just patients who underwent genotype identification included this analysis (8). HPV DNA detection in cervical swabs was conducted by using real-time polymerase chain reaction (PCR) with a commercial kit (Fluorion, Iontek, Turkey). For DNA extraction, the QIAamp DNA Mini Kit (Qiagen, Hilden, Germany) was used in accordance with the instructions of the manufacturer. A $150 \mathrm{bp}$ fragment of the L1 gene was amplified using GP5 and GP6 primers. An amplified gene product was identified via melting curve analysis and visualized by incorporation of Sybr Green dye during amplification. HPV genotyping was performed with DYEnamic ET Terminator Cycle Sequencing Kit (Amersham Biosciences Corp., NJ, USA) and ABI PRISM 310 Genetic Analyzer at Iontek Ltd, Turkey.

Statistical analysis: Chi-square method and Fisher's exact test were used for most of the analysis. Since age distribution on HPV positivity was not normally distributed, the MannWhitney-U Test was utilized. All tests of significance were done at the 5\% two-sided significance level. Statistical analysis was performed using SPSS 17 (Statistical Package for Social Sciences, Chicago, US).

\section{RESULTS}

A total of 6388 women who applied for regular gynecological examination were analyzed for HPV at twelve Health Centers in Turkey. Of these, 218 women were excluded from the analysis due to missing HPV DNA assessment and incomplete data. The study included data from 7 (58\%) university clinics and 5 (42\%) government hospitals. Sixty seven percent of the patients were married, while the remaining $33 \%$ were single or widowed. Fifty nine percent of the study population consisted of nulliparous women and the remaining $41 \%$ had at least one delivery. The vast majority of patients were between the $3^{\text {rd }}$ and $5^{\text {th }}$ decades and the mean age of the patients was $38.9 \pm 10.2$ (range 15-76 ) years. While $81 \%$ of the study population was premenopausal, the remaining $19 \%$ was menopausal. Overall, 25\% of the women were found to be HPV positive. 
Presence of HPV-DNA among patients with abnormal and normal cytology was $52 \%$ and $27 \%$, respectively. There was a statistically significant negative relationship between age and HPV positivity $(\mathrm{p}<0.05)$. The younger the age, the higher was the chance of HPV positivity. Furthermore as in the presence of significant differences with respect to HPV positivity between women under 30 years old and women older than 30 years old $(36.2 \%$ vs. $30.4 \%, \mathrm{p}<0.001)$, there were similar significant differences with respect to decades of life and HPV positivity ( $\mathrm{p}<0.05)$. HPV prevalence was significantly increased in premenopausal women $(32.5 \%)$ compared to menopausal women $(28.6 \%)(\mathrm{p}<0.05)$. While there were $76.5 \%$ women with normal cervical cytology, only $23.5 \%$ women with cervical cytological abnormality were diagnosed. HPV-DNA positivity among patients with abnormal and normal cytology was $52 \%$ and $27 \%$, respectively. HPV was positive in (within the HPV (+) patients) $37 \%, 9 \%, 27 \%, 20 \%, 22 \%$, and $41 \%$ of the ASCUS, ASC-H, LSIL HSIL, glandular cell abnormalities, and SCC respectively. Table I illustrates total distribution of cervical cytology and HPV results in the study population. The most common HPV types in our study were as follows; HPV 16 (32\%), HPV 6 (17\%), HPV 11 (9\%), HPV 18 (8\%), HPV 31 (6\%), HPV 51 (5\%), HPV 33 (3\%). Table II illustrates HPV types distribution. Figure 1, demonstrates HPV prevalence by decades and Figure 2 demonstrates High risk HPV prevalence by decades. Table III demonstrates the most common HPV types in different abnormal cytologies.

Table I: Distribution of cervical cytology with regard to HPV status in patients with abnormal cytology

\begin{tabular}{|c|c|c|c|c|c|}
\hline & & & \multicolumn{2}{|c|}{ HPV } & \multirow[b]{2}{*}{ Total } \\
\hline & & & Negative & Positive & \\
\hline \multirow[t]{3}{*}{ PAP Results } & ASCUS & $\mathrm{n}, \%$ & $406(35 \%)$ & $233(20 \%)$ & 639 (54\%) \\
\hline & LSIL & $\mathrm{n}, \%$ & $87(7 \%)$ & $170(14 \%)$ & $257(22 \%)$ \\
\hline & HSIL & $\mathrm{n}, \%$ & $29(3 \%)$ & $122(10 \%)$ & $151(13 \%)$ \\
\hline
\end{tabular}

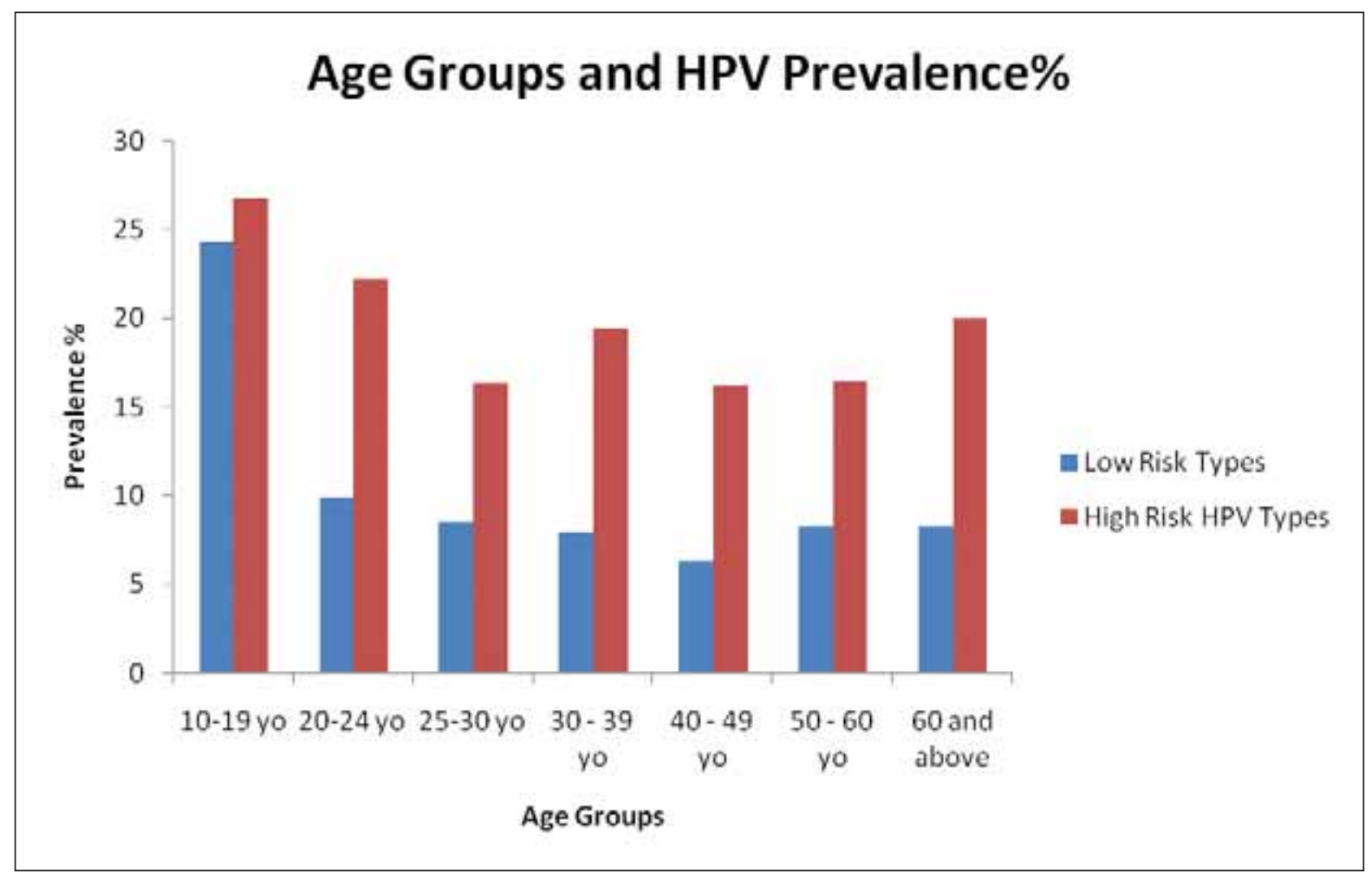

Figure 1: HPV prevalence by decades (yo: "years old"). 


\section{DISCUSSION}

Historically, two-milestone studies were published related the HPV and cervical cancer. In 1976 zur Hausen published the hypothesis that human papilloma virus plays an important role in the cause of cervical cancer. Thereafter in 1983 and 1984 zur Hausen and his collaborators identified HPV16 and HPV18 in cervical cancer (9). Today the cause and effect relationship between high-risk HPV infection and cervical cancer is clearly established (10). Cervical cancer is an important health problem worldwide, with an annual incidence of 500.000 cases and $50 \%$ case fatality rate (2). Over $120 \mathrm{HPV}$ types have been identified and are referred to by number. Types $16,18,31,33,35,39,45,51,52,56$, $58,59,68,73$, and 82 are carcinogenic "high-risk" sexually transmitted HPVs and may lead to the development of cervical intraepithelial neoplasia (CIN) (11).

Knowledge of HPV prevalence and type distribution in a selected population is important, as it may affect vaccination and treatment strategies. Earlier studies have reported that HPV prevalence among low risk Turkish women ranges between 2-6\% (12,13). However, reliable data on HPV type distribution in this population is lacking. This study has been conducted to gather reliable data on prevalence and type distribution of HPV-DNA in a Turkish population.

Many studies demonstrated that the prevalence of women infected with human papillomavirus and the distribution of HPV types varies greatly across populations worldwide. Prevalence of HPV in our study was $25 \%$, which is similar to those reported worldwide. However previous studies from Turkey had reported this figure was much lower (between $2 \%-6 \%)(13,14,14,16)$ compared with western countries. But in our study HPV prevalence determined as high as $25 \%$ contrary to previous studies. This discrepancy may be explained by the hospital-based accrual of the patients as well as number of patients included in the studies, educational levels and knowledge about HPV and cervical cancer of the subjects $(17,18)$. Our study is the largest series that we believe is the most reliable results from Turkey with respect to HPV types in Turkey. However, we have to emphasize that this high rate of the prevalence cannot reflects to real HPV prevalence in Turkey. Furthermore technological improvement for the HPV evaluating methods may affect the results (19). Barring the data from Hacettepe University, in our study, all HPV-DNA analysis was performed via PCR methods whereas in three studies previously published from Turkey, HC (Hybrid Capture] was used for the analysis $(13,14,15,16)$. In a pathological evaluation of the cervical cancer specimens, Usubütün et al. (20) reported that HPV prevalence was 93.5\% (232/248;
Table II: Distribution of the HPV types in the study population

\begin{tabular}{|c|c|c|}
\hline HPV types & Frequency (n) & Percent (\%) \\
\hline 16 & 509 & 32 \\
\hline 6 & 274 & 17 \\
\hline 11 & 141 & 9 \\
\hline 18 & 124 & 8 \\
\hline 31 & 103 & 6 \\
\hline 51 & 75 & 5 \\
\hline 33 & 48 & 3 \\
\hline 53 & 39 & 2 \\
\hline 52 & 35 & 2 \\
\hline 45 & 31 & 2 \\
\hline 66 & 30 & 2 \\
\hline 35 & 26 & 2 \\
\hline 68 & 23 & 1 \\
\hline 39 & 14 & .9 \\
\hline 50 & 13 & .8 \\
\hline 56 & 12 & .8 \\
\hline 30 & 9 & .6 \\
\hline 70 & 9 & .6 \\
\hline 54 & 8 & .5 \\
\hline 17 & 7 & .3 \\
\hline 42 & 6 & .4 \\
\hline 58 & 6 & .4 \\
\hline 59 & 6 & .3 \\
\hline 44 & 5 & .3 \\
\hline 16,18 & 5 & .3 \\
\hline 26 & 4 & .3 \\
\hline 40 & 4 & .3 \\
\hline 82 & 4 & .3 \\
\hline 32 & 3 & .1 \\
\hline $31,33,45,52,58$ & 3 & .2 \\
\hline 34 & 2 & .1 \\
\hline 43 & 2 & .1 \\
\hline 90 & 2 & .1 \\
\hline 5 & 1 & .1 \\
\hline 8 & 1 & .1 \\
\hline 61 & 1 & .1 \\
\hline 67 & 1 & .1 \\
\hline 81 & 1 & .1 \\
\hline 95 & 1 & .1 \\
\hline Total & 1588 & 100.0 \\
\hline
\end{tabular}


Table III: Most common HPV types in patients with abnormal cytology

\begin{tabular}{|l|c|c|c|}
\hline & ASCUS & LSIL & HSIL \\
\hline HPV-16 & $67(29.8 \%)$ & $55(41.4 \%)$ & $66(68.8 \%)$ \\
\hline HPV-6 & $28(12.4 \%)$ & $12(9 \%)$ & $4(4.2 \%)$ \\
\hline HPV-31 & $24(10.7 \%)$ & $10(7.5 \%)$ & $3(3.1 \%)$ \\
\hline HPV-11 & $20(8.9 \%)$ & $3(2.3 \%)$ & $3(3.1 \%)$ \\
\hline HPV-18 & $17(7.6 \%)$ & $14(10.5 \%)$ & $4(4.2 \%)$ \\
\hline HPV-33 & $9(4 \%)$ & $4(3 \%)$ & $4(4.2 \%)$ \\
\hline
\end{tabular}

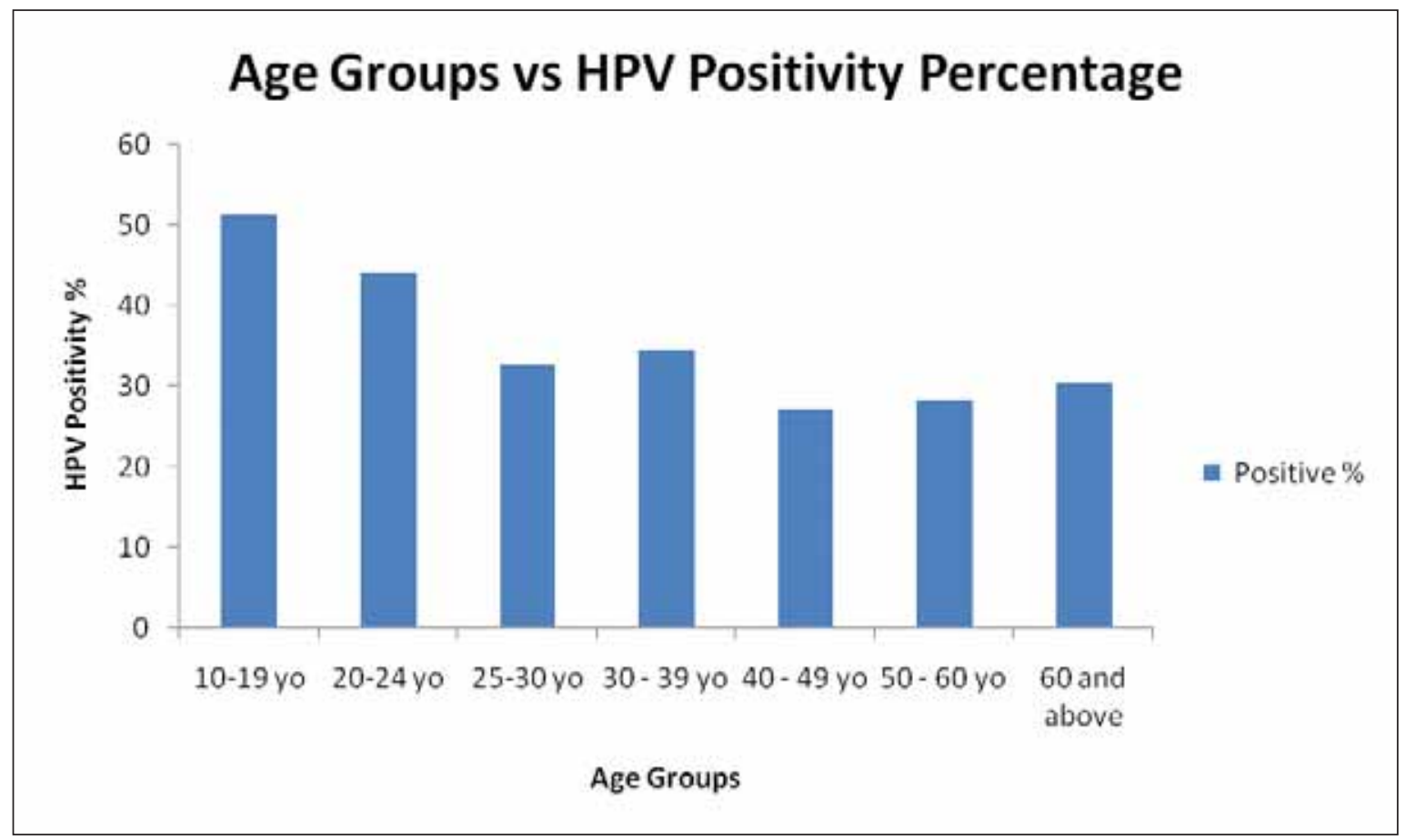

Figure 2: High risk HPV prevalence by decades (yo: "years old").

95\% confidence interval: 90.5\%-96.6\%). The five most common HPV types identified as single types among HPVpositive cases were HPV16 (64.7\%), HPV18 (9.9\%), HPV45 (9.9\%), HPV31 (3.0\%), and HPV33 (2.2\%) (20). Similar to our study, HPV 16 and 18 were the most common high risk HPV in this study as well.

We found the presence of HPV in women with abnormal cytology was $53 \%$, which is consistent with literature. In previous studies, HPV was reported in $29 \%-61 \%$ in women with abnormal cytology results $(21,22,23,24,25,26)$. In our study, the rate of HPV positivity in women with normal cervical cytology was 27\%, reflecting hospital based patients' accrual. In 2007 a meta-analysis of 78 studies, in 2008 a meta-analysis of 79 studies in women with normal cervical cytology, overall HPV was reported $10.4 \%$ and $14.4 \%$ respectively (18). On the other hand, in an another meta-analysis including the results of 15.613 women, overall HPV prevalence was $8.7 \%, 14.3 \%$ and $5.2 \%$ for Asia, South America and Europe, respectively (19). The discrepancy between the various studies could be explained by the false negative results of Pap testing and differences in the population with respect to risk factors for HPV and the method used for evaluations. In literature, multiple presences of HPV genotypes have been reported to occur in $10 \%$ to $20 \%$ of HPV-positive cases (24). As a matter of fact, we only found less than $1 \%$ of HPV-infected women with multiple HPV genotypes. We believe that is most likely due to the nature of data collection from different centers retrospectively.

In literature, HPV prevalence in women younger and older than 25 years old has been reported between $32-64 \%$ and between 2-4\%, respectively (25). Furthermore Sellors et al. reported a significant reduction in HPV prevalence throughout the third decade of life (27). Similarly, in our 
study differences between women less than 30 years old and women older than 30 years old with respect to HPV positivity were significant. We also found significant differences in HPV prevalence by the decades of life (Figure 1, 2). HPV prevalence and high risk HPV was more common in women with younger age.

In this study, the most common HPV types were as follows; HPV-16, HPV-6, HPV-11, and HPV-18. Although HPV-16 is known to be the most prevalent type and HPV-18 is the second most common type worldwide, our results show similarity with western countries with respect to HPV type distribution (24). Within the HPV positive patients in our study population the most common cytological abnormalities was as follows: SCC, ASCUS, LSIL, and HSIL. Similarly in the literature, there is a strong association between abnormal cervical cytological results and the presence of carcinogenic types of HPV.

In conclusion, heterogeneity in HPV type distribution among women from different populations should be taken into account when developing screening tests for the virus and predicting the effect of vaccines on the incidence of infection. In spite of higher HPV prevalence in our study compared with previous studies reported from Turkey, HPV prevalence and genotypes in Turkish women with normal and abnormal cytology are similar to those reported from western countries. Population-based data for HPV type distribution is necessary to the development of new HPV screening tests and to assessment of the effect of future vaccination. These results may also provide baseline information about the HPV prevalence and may help to guide vaccination policies in Turkey. Although our data was collected in almost all regions from Turkey, it is important to acknowledge that it was a hospital based study. Therefore further population based prospective multicenter studies are necessary to determine more precise hospital and nonhospital based HPV prevalence in Turkish women.

\section{REFERENCES}

1. Armstrong EP: Prophylaxis of cervical cancer and related cervical disease: A review of the cost-effectiveness of vaccination against oncogenic HPV types. Journal of Managed Care Pharmacy 2010, 16: $217-230$

2. World Health Organization (February 2006). Fact sheet No. 297: Cancer. Retrieved 2007-12-01

3. GLOBOCAN 2002 [database online]: Summary table by cancer. Archived from the original on 2008-06-16. Retrieved 2008-10-26

4. NCCC National Cervical Cancer Coalition. Archived from the original on 2008-08-22. Retrieved 2008-07-01
5. Canavan TP, Doshi NR: Cervical cancer. Am Fam Physician 2000, 61: 1369-1376

6. Dursun P, Senger SS, Arslan H, Kuşçu E, Ayhan A: Human papillomavirus (HPV) prevalence and types among Turkish women at a gynecology outpatient unit. BMC Infect Dis 2009, 9:191

7. Solomon D, Davey D, Kurman R, Moriarty A, O'Connor D, Prey M, Raab S, Sherman M, Wilbur D, Wright T Jr, Young N; Forum Group Members; Bethesda 2001 Workshop: The 2001 Bethesda System: Terminology for reporting results of cervical cytology. JAMA 2002, 287:2114-2119

8. Evans MF, Adamson CS, Papillo JL, St John TL, Leiman G, Cooper K: Distribution of human papillomavirus types in thinprep papanicolaou tests classified according to the Bethesda 2001 terminology and correlations with patient age and biopsy outcomes. Cancer 2006, 106:1054-1064

9. World Health Organization, Human papillomaviruses International Agency for Research on Cancer 2007. ISBN 978-92-8321290-4

10. Marrazzo JM, Koutsky LA, Kiviat NB, Kuypers JM, Stine K: Papanicolaou test screening and prevalence of genital human papillomavirus among women who have sex with women. Am J Public Health 2001, 91: 947-952

11. Muñoz N, Bosch FX, de Sanjosé S, Herrero R, Castellsagué X, Shah KV, Snijders PJ, Meijer CJ: Epidemiologic classification of human papillomavirus types associated with cervical cancer. N Engl J Med 2003, 348: 518-527

12. Inal MM, Köse S, Yildirim Y, Ozdemir Y, Töz E, Ertopçu $K$, Ozelmas I, Tinar S: The relationship between human papillomavirus infection and cervical intraepithelial neoplasia in Turkish women. Int J Gynecol Cancer 2007, 7:1266-1270

13. Ozcelik B, Serin IS, Gokahmetoglu S, Basbug M, Erez R: Human papillomavirus frequency of women at low risk of developing cervical cancer: A preliminary study from a Turkish university hospital. Eur J Gynaecol Oncol 2003, 24:157-159

14. Tuncer ZS, Basaran M, Ustaçelebi S, Kuzey GM: High-Risk Human Papilloma Virus (HPV) Infection Determined By Hybrid Capture II Assay in a Turkish University Hospital Outpatient. Clinic MN-Gorm 2006, 12:129-134

15. Seçkin S, Aksoy F, Yıldırım M: Servikal smearlerde HPV infeksiyonu görülme indisansı. Ankara Numune Eğitim ve Arastırma Hastanesi Tip Dergisi 1996, 36:101-103

16. Safi Z, Demirezen S, Beksaç MS, Kuzey GM, Kocagöz T, Ustaçelebi Ş, Hasçelik G, Çakar An: İnsan papilloma virüsünün (IPV) polimeraz zincir reaksiyonu tekniği ile servikal ve vajinal akıntı örneklerinde saptanması. MN-Klinik Bilimler\&Doktor 2002, 8:112-114

17. Bao YP, Li N, Smith JS, Qiao YL, ACCPAB: Human papillomavirus type distribution in women from Asia: A metaanalysis. Int J Gynecol Cancer 2008, 18:71-79

18. de Sanjosé S, Diaz M, CastellsaguéX, Clifford G, Bruni L, Muñoz N, Bosch FX: Worldwide prevalence and genotype distribution of cervical human papillomavirus DNA in women with normal cytology: A meta-analysis. Lancet Infect Dis 2007, 7:453-459 
19. Clifford GM, Gallus S, Herrero R, Muñoz N, Snijders PJ, Vaccarella S, Anh PT, Ferreccio C, Hieu NT, Matos E, Molano M, Rajkumar R, Ronco G, de Sanjosé S, Shin HR, Sukvirach S, Thomas JO, Tunsakul S, Meijer CJ, Franceschi S; IARC HPV Prevalence Surveys Study Group: Worldwide distribution of human papillomavirus types in cytologically normal women in the International Agency for Research on Cancer HPV prevalence surveys: A pooled analysis. Lancet 2005, 366:991-998

20. Usubütün A, Alemany L, Küçükali T, Ayhan A, Yüce K, de Sanjosé S, Font R, Lloveras B, Klaustermeier J, Quint W, Muñoz N, Bosch FX: Human papillomavirus types in invasive cervical cancer specimens from Turkey. Int J Gynecol Pathol 2009, 28:541-548

21. Rowe LR, Aldeen W, Bentz JS: Prevalence and typing of HPV by hybrid capture in women with ASCUS, ASC-H and AGC on ThinPrep Pap test. Diagn Cytopathol 2004, 30:426-432

22. González-Bosquet E, Esteva C, Muñoz-Almagro C, Ferrer P, Pérez M, Lailla JM: Identification of vaccine human papillomavirus genotypes in squamous intraepithelial lesions (CIN2-3). Gynecol Oncol 2008, 111:9-12
23. Levert M, Clavel C, Graesslin O, Masure M, Birembaut P, Quereux C, Gabriel R: Human papillomavirus typing in routine cervical smears. Result from a series of 3778 patients. Gynecol Obstet Fertil 2000, 28:722-728

24. Hwang HS, Park M, Lee SY, Kwon KH, Pang MG: Distribution and Prevalence of Human Papillomavirus Genotypes in Routine Pap Smear of 2,470 Korean Women Determined by DNA Chip. Cancer Epidemiol Biomarkers Prev 2004, 13:2153-2156

25. Burk RD, Kelly P, Feldman J, Bromberg J, Vermund SH, DeHovitz JA, Landesman SH: Declining prevalence of cervicovaginal human papillomavirus infection with age is independent of other risk factors. Sex Transm Dis 1996, 23:333-341

26. Prevalence of Abnormal Cervical Cytology in Turkey: A Turkish Gynecologic Oncology Group study. Turkish Cervical Cancer and Cervical Cytology Research Group. Int J Gynaecol Obstet 2009, 106:206-209

27. Sellors JW, Mahony JB, Kaczorowski J, Lytwyn A, Bangura H, Chong S, Lorincz A, Dalby DM, Janjusevic V, Keller JL: Prevalence and pre- dictors of human papilloma virus infection in women in Ontario, Canada. Survey of HPV in Ontario Women (SHOW) Group. CMAJ 2000, 163:503-508 